\title{
Diurnal rhythm of plasma 1,25-dihydroxyvitamin D and vitamin D-binding protein in postmenopausal women: relationship to plasma parathyroid hormone and calcium and phosphate metabolism
}

\author{
Lars Rejnmark $^{1,2}$, Anna L Lauridsen ${ }^{3}$, Peter Vestergaard ${ }^{1,4}$, Lene Heickendorff ${ }^{5}$, Frederik Andreasen ${ }^{2}$ and \\ Leif Mosekilde ${ }^{1,4}$ \\ ${ }^{1}$ Department of Endocrinology and Metabolism C, Aarhus Amtssygehus, Aarhus University Hospital, ${ }^{2}$ Department of Clinical Pharmacology, Faculty of \\ Health Sciences, Aarhus University, ${ }^{3}$ Department of Clinical Biochemistry, AKH, Aarhus University Hospital, ${ }^{4}$ Faculty of Health Sciences, \\ Aarhus University and ${ }^{5}$ Department of Clinical Biochemistry, Aarhus Amtssygehus, Aarhus University Hospital, Aarhus, Denmark
}

(Correspondence should be addressed to L Rejnmark, Department of Endocrinology and Metabolism C, Aarhus Amtssygehus, Aarhus University Hospital, Tage-Hansens Gade 2, DK-8000 Aarhus C, Denmark; Email: rejnmark@post6.tele.dk)

\begin{abstract}
Objective: Diurnal variations in plasma levels of 1,25-dihydroxyvitamin $\mathrm{D}\left(1,25(\mathrm{OH})_{2} \mathrm{D}\right)$ have previously only been investigated in young individuals, and these studies have failed to demonstrate a diurnal rhythm. We have studied whether plasma levels of $1,25(\mathrm{OH})_{2} \mathrm{D}$ and vitamin D-binding protein (DBP) vary in a diurnal rhythm in postmenopausal women.

Methods: Blood and urine were sampled with 2- and 4-h intervals in order to assess diurnal variations in plasma levels of $1,25(\mathrm{OH})_{2} \mathrm{D}, \mathrm{DBP}$ and parathyroid hormone (PTH), as well as in plasma levels and urinary excretion rates of calcium and phosphate. Additionally, the free $1,25(\mathrm{OH})_{2} \mathrm{D}$ index was calculated (the molar ratio of $1,25(\mathrm{OH})_{2} \mathrm{D}$ to $\mathrm{DBP}$ ).

Results: Plasma $1,25(\mathrm{OH})_{2} \mathrm{D}$ exhibited a diurnal rhythm $(P<0.01)$ with a nadir in the morning $(99 \pm 12 \mathrm{pmol} / \mathrm{l})$, followed by a rapid increase to a plateau during the day $(113 \pm 13 \mathrm{pmol} / \mathrm{l}$, i.e. $14 \%$ above nadir level; $P=0.005)$. A similar pattern of variation was found in plasma levels of DBP with peak levels $15 \%$ above nadir levels $(P<0.01)$. The free $1,25(\mathrm{OH})_{2} \mathrm{D}$ index did not vary in a diurnal rhythm. PTH and plasma levels and urinary excretions of calcium and phosphate exhibited a diurnal pattern of variation. The diurnal rhythm of DBP was correlated with the rhythm of $1,25(\mathrm{OH})_{2} \mathrm{D}(r=0.47, P<0.01)$ and plasma albumin $(r=0.76, P<0.01)$. Moreover, the rhythm of plasma calcium and PTH varied inversely $(r=-0.36, P=0.02)$.

Conclusions: With the disclosure of a diurnal rhythm of total plasma $1,25(\mathrm{OH})_{2} \mathrm{D}$, all major hormones and minerals related to calcium homeostasis have now been shown to exhibit diurnal variations. In clinical studies, the diurnal variations of $1,25(\mathrm{OH})_{2} \mathrm{D}$ and DBP must be considered, i.e. blood sampling must be standardised according to the time of day.
\end{abstract}

European Journal of Endocrinology 146 635-642

\section{Introduction}

Vitamin D plays a major role in calcium homeostasis and bone turnover. 1,25-Dihydroxyvitamin D $\left(1,25(\mathrm{OH})_{2} \mathrm{D}\right)$ is the predominant biologically active metabolite of vitamin D. In plasma, only a small fraction of $1,25(\mathrm{OH})_{2} \mathrm{D}$ is free, as most of it is bound to the vitamin D-binding protein (DBP). The renal synthesis of $1,25(\mathrm{OH})_{2} \mathrm{D}$ is tightly regulated by plasma levels of parathyroid hormone (PTH), calcium and phosphate $(1,2)$. A diurnal variation is well documented in plasma levels of PTH, as well as in plasma levels and urinary excretion rates of calcium and phosphate, and in biochemical markers of bone turnover. These diurnal variations have been demonstrated in young as well as in elderly men and women (3-5). The diurnal changes in plasma levels of PTH, calcium and phosphate may exert important effects on bone remodelling, whereas the diurnal variation in urinary excretion rates and biochemical bone markers may be the result of a diurnal variation in bone turnover, as well as possibly being affected by the time at which food is consumed. Greater amplitude in the diurnal rhythm of PTH has been observed in normal than in osteoporotic subjects (4) and in men than in women $(3,6)$. Such rhythms may have clinical implications for the 
timing of sample collection and assessment of therapeutic intervention.

As the diurnal rhythms of PTH, calcium, phosphate and biochemical bone markers have been shown to be highly interrelated and because of the intimate relationships between calcium, phosphate, PTH and $1,25(\mathrm{OH})_{2} \mathrm{D}$, it seems reasonable to expect that plasma levels of $1,25(\mathrm{OH})_{2} \mathrm{D}$ may also vary in a diurnal pattern. Nevertheless, fluctuations in plasma concentration of $1,25(\mathrm{OH})_{2} \mathrm{D}$ have only been investigated in a few studies. In young men, Halloran et al. (7) found no apparent diurnal pattern of variation in total plasma concentrations of $1,25(\mathrm{OH})_{2} \mathrm{D}$. Furthermore, no correlation was found between plasma levels of $1,25(\mathrm{OH})_{2} \mathrm{D}$ and plasma concentrations of either calcium or phosphate. Likewise, Adams et al. (8) and Prince et al. (9) found no effect of time of day on total plasma concentration of $1,25(\mathrm{OH})_{2} \mathrm{D}$ in young men and women. Diurnal fluctuations in DBP have not been investigated in previous studies.

As all prior studies, apparently, have been performed on young individuals, we re-addressed the question of whether there are diurnal fluctuations in the plasma concentration of $1,25(\mathrm{OH})_{2} \mathrm{D}$ in a group of postmenopausal women. Additionally, we measured diurnal variations in plasma DBP levels, and calculated the free $1,25(\mathrm{OH})_{2} \mathrm{D}$ index as a measure of diurnal fluctuations in the free fraction of $1,25(\mathrm{OH})_{2} \mathrm{D}$.

\section{Subjects and methods}

We studied twelve women aged 58 years on average (range 50-71). All of them were more than 12 months postmenopause. All had previously sustained a distal forearm fracture (at least 6 months prior to entering the study) but were otherwise healthy. They were recruited through a computer database at the two casualty departments at the University Hospital of Aarhus, Denmark. Subjects with illnesses or medications (including hormone replacement therapy) known to affect bone mineral metabolism or with plasma creatinine above $105 \mu \mathrm{mol} / \mathrm{l}$ were excluded. All patients were carefully screened by medical examination and through a standard biochemical investigation. Each individual gave verbal and written informed consent prior to the study. The study was approved by the regional Ethical Committee (Aarhus County no. 1997/4019) and was conducted according to the Declaration of Helsinki II.

\section{Experimental conditions and measurements}

All subjects were studied in a clinical research ward for a 24-h period that lasted from $1000 \mathrm{~h}$ until $1000 \mathrm{~h}$ the following day. Throughout the study period, participants were kept under close staff supervision. Normal activity was allowed during the day. Main meals (ordinary hospital food) were served at 1200, 1800 and $0800 \mathrm{~h}$. Subjects slept from 2400 to $0800 \mathrm{~h}$. Blood samples were drawn at 1000, 1200, 1400, $1600,2000,2400,0400$ and $0800 \mathrm{~h}$ (fasting) through an indwelling venous catheter placed in a forearm vein. Urine was collected in eight separate collections at the same times as blood samples were drawn to represent intervals between blood sampling. Just before the start of the study (at $1000 \mathrm{~h}$ ) and at the end of each collection period, subjects were instructed to empty the bladder. Blood samples were allowed to clot for $10 \mathrm{~min}$ and then centrifuged for $10 \mathrm{~min}$ at 2500 g. Plasma and urine samples for standard chemistry were refrigerated at $5^{\circ} \mathrm{C}$ until analysis the next day. We measured plasma total calcium (P-Ca total), phosphate (P-Ph), creatinine and albumin (P-albumin), as well as urinary calcium (U-Ca) and phosphate (U-Ph) by standard methods on an automated chemistry analyser (Hitachi 917; Roche Diagnostics Corporation, Indianapolis, IN, USA). Plasma calcium was adjusted for individual variations in plasma albumin according to the formula (adjusted plasma calcium): $(\mathrm{P}-\mathrm{Ca}(\mathrm{mmol} / \mathrm{l}))=\mathrm{P}-\mathrm{Ca}_{\text {total }}(\mathrm{mmol} / \mathrm{l})$ $-0.00086 \times(650-\mathrm{P}$-albumin $(\mu \mathrm{mol} / \mathrm{l}))$. Additional plasma samples were divided into aliquots and stored immediately at $-80^{\circ} \mathrm{C}$ until analysis. To reduce analytical variation, calcitropic hormones from each patient were analysed in the same run. For each measured variable, the inter- and intra-assay coefficients of variation (CV) were established in our laboratory.

Plasma intact PTH was measured by an IMMULITE automated analyser using a solid-phase, two-site chemiluminescent enzyme immunometric assay (IMMULITE Intact PTH; Diagnostic Products Corporation, Los Angeles, CA, USA). The inter- and intra-assay $\mathrm{CV}$ values were 7 and 6\% respectively. Plasma 25-hydroxyvitamin D (25(OH)D) was measured by a two-step procedure. Following extraction from plasma with acetonitrile, 25(OH)D was assayed using an equilibrium radioimmunoassay procedure (DiaSorin Inc., Stillwater, MN, USA). The inter- and intra-assay $\mathrm{CV}$ values were 13 and $10 \%$ respectively. Plasma $1,25(\mathrm{OH})_{2} \mathrm{D}$ was purified from other lipid components in the plasma by an extraction procedure using acetonitrile and a phosphate buffer with subsequent chromatographic purification through a $\mathrm{C}_{18} \mathrm{OH}$ column. Correction was made for the recovery of $1,25(\mathrm{OH})_{2} \mathrm{D}$. Quantification of $1,25(\mathrm{OH})_{2} \mathrm{D}$ was achieved by a competitive radioreceptor assay using a calf thymus vitamin D receptor as the ligand binder (1,25-dihydroxyvitamin D kit; Nichols Institute Diagnostics, San Juan Capistrano, CA, USA). The inter- and intra-assay $\mathrm{CV}$ values were 10 and $8 \%$ respectively.

Plasma DBP was measured by an immunonephelometric method as described by Lauridsen et al. (10). We used a Behring Nephelometer II (Dade Behring, Marburg, Germany) and the interassay $\mathrm{CV}$ was less than 5\%. As a 
measure of the free fraction $1,25(\mathrm{OH})_{2} \mathrm{D}$, the free $1,25(\mathrm{OH})_{2} \mathrm{D}$ index was calculated as the molar ratio of $1,25(\mathrm{OH})_{2} \mathrm{D}$ to DBP.

The individual mean plasma creatinine value was calculated for each urine collection period, using the values at the beginning and end of the collection periods. These mean values were used to calculate renal clearances of creatinine $(\mathrm{ClCr})$. The ratio between the tubular maximal reabsorption of phosphate and the glomerular filtration rate (TmP/GFR) was calculated according to Bijvoet et al. (11).

\section{Statistical methods}

For each plasma response variable, the individual values were plotted against time, and area under the curve was calculated by trapezoidal integration and transformed to a mean integrated plasma value (i.e. the average 24-h level) by division with the length of the study period $(24 \mathrm{~h})$. Data are expressed as a percentage of the individual 24-h average value. For each urinary response variable, 24-h renal excretion was calculated as the sum of the individual sample measurements (volume $\times$ concentration). For each collection period, renal excretion was expressed by the excretion rate $(\mathrm{mmol} / \mathrm{h})$ as a percentage of the individual 24-h average value. The mean percentage value for each response variable was plotted against time in order to construct a diurnal variation curve.

Normal distribution of data was evaluated using normal probability and detrended normal probability plots. The presence of a diurnal rhythm was assessed (on raw data) in two ways. First, peak and nadir levels were compared using Student's $t$-test for paired samples or Wilcoxon signed rank test, as appropriate. Secondly, diurnal rhythm was tested as an effect of time by repeated measures ANOVA.

In order to minimise intra- and inter-individual variation, data were transformed into z-scores (difference from intra-individual mean divided by intra-individual standard deviation) allowing the pattern of variation to become more apparent. Relationship between variables was assessed by bivariate and multiple stepwise linear regression analysis. The Pearson's productmoment correlation $(r)$ was determined between variables using data paired at concurrent time-points. All tests were performed as two-sided and $P$ values less than 0.05 were considered significant. Results are given as means \pm S.E.M.

Table 1 Clinical characteristics of the 12 women; median (range).

\begin{tabular}{lcc}
\hline Age (years) & 57.0 & $(50-71)$ \\
Years since menopause & 9.0 & $(1-20)$ \\
Weight $(\mathrm{kg})$ & 61.7 & $(50.5-75.0)$ \\
Height $(\mathrm{cm})$ & 163 & $(157-169)$ \\
Body mass index $\left(\mathrm{kg} / \mathrm{m}^{2}\right)$ & 23.2 & $(19.2-27.3)$ \\
\hline
\end{tabular}
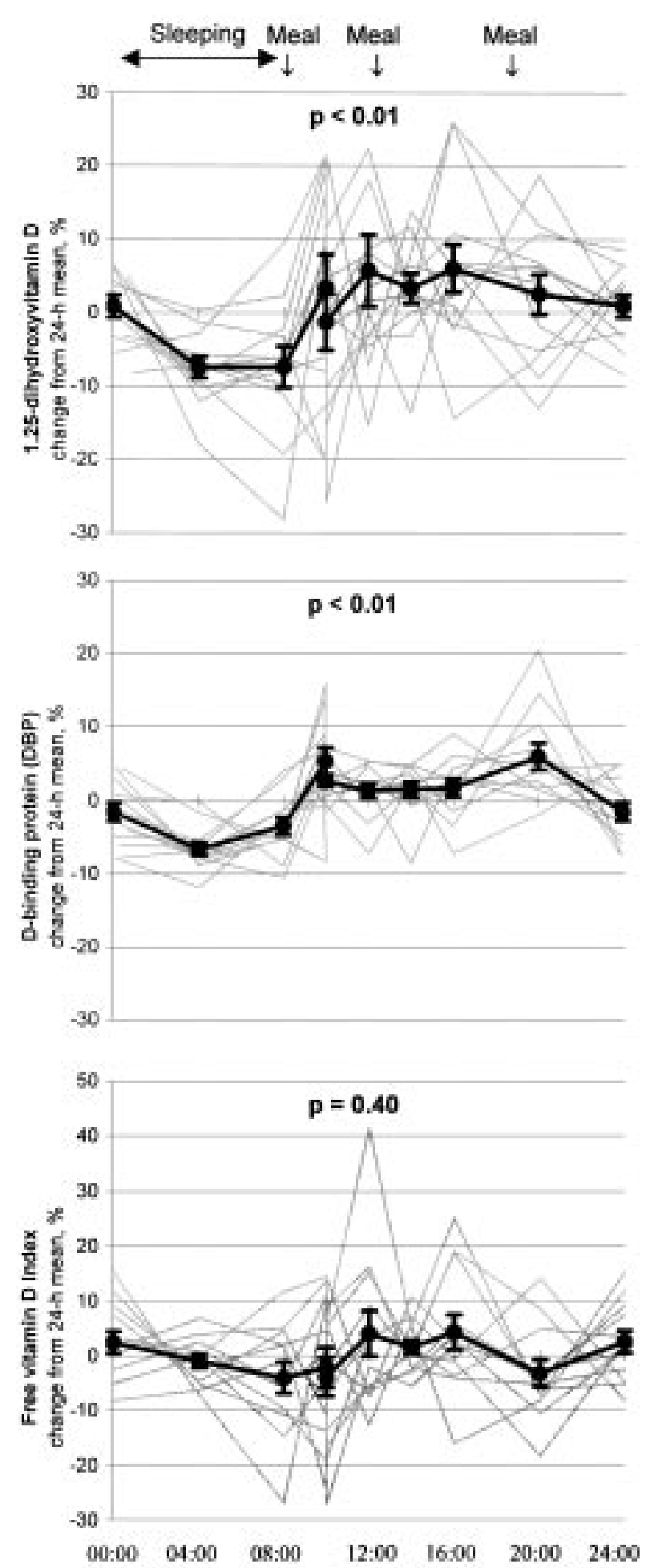

Figure 1 Individual and mean \pm S.E.M. (bold lines) diurnal variation in plasma levels of 1,25 dihydroxyvitamin $\mathrm{D}\left(1,25(\mathrm{OH})_{2} \mathrm{D}\right)$, vitamin D-binding protein (DBP) and in the calculated free $1,25(\mathrm{OH})_{2} \mathrm{D}$ index. The study period started at $1000 \mathrm{~h}$ and meals were served at 1200,1800 and $0800 \mathrm{~h}$. Subjects were sleeping (recumbent) from 2400 until $0800 \mathrm{~h}$. 
Table 2 Biochemical characteristics of the 12 women (means \pm S.E.M.).

\begin{tabular}{lcc} 
& Pre-study screening & Reference range \\
\hline Plasma (morning fasting samples) & & \\
Albumin $(\mu \mathrm{mol} / \mathrm{l})$ & $639 \pm 10$ & $(551-725)$ \\
Creatinine $(\mu \mathrm{mol} / \mathrm{l})$ & $84 \pm 2$ & $(44-115)$ \\
Calcium $(\mathrm{total})(\mathrm{mmol} / \mathrm{l})$ & $2.40 \pm 0.02$ & $(2.20-2.55)$ \\
Calcium $(\mathrm{adjusted})(\mathrm{mmol} / \mathrm{l})$ & $2.39 \pm 0.01$ & $(2.20-2.52)$ \\
Phosphate $(\mathrm{mmol})$ & $1.32 \pm 0.06$ & $(0.80-1.50)$ \\
$\mathrm{PTH}(\mathrm{pmol} / \mathrm{l})$ & $4.2 \pm 0.4$ & $(1.3-7.6)$ \\
$25(\mathrm{OH}) \mathrm{D}(\mathrm{nmol} / \mathrm{l})$ & $36 \pm 4$ & $(40-80) \dagger$ \\
$1,25(\mathrm{OH})_{2} \mathrm{D}(\mathrm{pmol} / \mathrm{l})$ & $107 \pm 13$ & $(3.6-6.1)$ \\
DBP $(\mu \mathrm{mol} / \mathrm{l})$ & $4.4 \pm 0.2$ & $\mathrm{NA}$ \\
TmP/GFR $(\mathrm{mmol} / \mathrm{l})$ & $1.2 \pm 0.1$ & $(1.0-1.7)$ \\
CICr $(\mathrm{ml} / \mathrm{s})$ & $1.2 \pm 0.1$ & $\mathrm{NA}$ \\
Urine $(24 \mathrm{~h})$ & & $\mathrm{NA}$ \\
Creatinine $(\mathrm{mmol})$ & $8.8 \pm 0.6$ & $\mathrm{NA}$ \\
Calcium/creatinine $(\mathrm{mmol} / \mathrm{mmol})$ & $0.5 \pm 0.1$ & \\
Phosphate/creatinine $(\mathrm{mmol} / \mathrm{mmol})$ & $2.2 \pm 0.2$ & \\
\hline
\end{tabular}

† Winter reference values (patients were studied between September and May).

PTH, parathyroid hormone; TmP/GFR, tubular maximal reabsorption of phosphate/glomerular filtration rate; $\mathrm{ClCr}$, creatine clearance; NA, not available.

\section{Results}

The clinical and biochemical characteristics of the twelve women are given in Table 1 and Table 2. Figure 1 shows the mean plasma $1,25(\mathrm{OH})_{2} \mathrm{D}$, DBP and free $1,25(\mathrm{OH})_{2} \mathrm{D}$ index curves and the individual levels in the twelve subjects. Inspection of individual curves revealed a large variation in the pattern of the rhythms. However, despite this heterogeneity, diurnal rhythms were apparent in plasma levels of $1,25(\mathrm{OH})_{2} \mathrm{D}$ and DBP, and the time-effect analyses disclosed highly significant diurnal patterns of variation $(P<0.01)$. Concentrations peaked in the day time, declined in the early evening, with a nadir late at night, followed by rising values in the forenoon. As shown in Table 3, the peak level of $1,25(\mathrm{OH})_{2} \mathrm{D}$ at $1600 \mathrm{~h}$ was $14 \%$ above nadir level at $0400 \mathrm{~h}(P=$ 0.005). Similarly, the peak level of DBP at $2000 \mathrm{~h}$ was $15 \%$ above nadir levels at $0400 \mathrm{~h}(P<0.01)$. However, as the rhythm of total $1,25(\mathrm{OH})_{2} \mathrm{D}$ was close to the rhythm of DBP $(r=0.47, P<0.01$; Table 4), no diurnal variation could be demonstrated in the free $1,25(\mathrm{OH})_{2} \mathrm{D}$ index $(P=0.40)$.

Plasma PTH, calcium (total and albumin corrected), phosphate and albumin (Fig. 2), as well as the renal handling of calcium and phosphate (Fig. 3) were all found to exhibit significant diurnal variations (Table 2). Moreover, a significant difference was observed when peak and nadir levels were compared (Table 3).

Table 3 Diurnal variation. Peak and nadir levels and effect of time analyses (means \pm S.E.M.).

\begin{tabular}{|c|c|c|c|c|c|c|c|}
\hline & \multicolumn{2}{|c|}{ Peak } & \multicolumn{2}{|c|}{ Nadir } & \multicolumn{2}{|c|}{ Peak vs nadir } & \multirow{2}{*}{$\frac{24 \mathrm{~h} \text { study period }}{P \dagger}$} \\
\hline & Clock hour & Means \pm S.E.M. & Clock hour & Means \pm S.E.M. & Amplitude (\%) & $P$ & \\
\hline \multicolumn{8}{|l|}{ Plasma } \\
\hline Albumin $(\mu \mathrm{mol} / \mathrm{l})$ & 1600 & $634 \pm 7$ & 0400 & $566 \pm 10$ & 12.0 & $<0.01$ & $<0.01$ \\
\hline Creatinine $(\mu \mathrm{mol} / \mathrm{l})$ & 1400 & $90 \pm 3$ & 1200 & $78 \pm 2$ & 15.4 & 0.01 & $<0.01$ \\
\hline Calcium (adjusted) (mmol/l) & 1000 & $2.43 \pm 0.02$ & 0800 & $2.36 \pm 0.01$ & 3.0 & $<0.01$ & $<0.01$ \\
\hline Phosphate $(\mathrm{mmol} / \mathrm{l})$ & 0400 & $1.53 \pm 0.05$ & 1000 & $1.23 \pm 0.06$ & 24.4 & $<0.01$ & $<0.01$ \\
\hline PTH (pmol/l) & 2000 & $4.7 \pm 0.5$ & 1000 & $3.5 \pm 0.3$ & 34.3 & $<0.01$ & $<0.01$ \\
\hline $1.25(\mathrm{OH})_{2} \mathrm{D}(\mathrm{pmol} / \mathrm{l})$ & 1600 & $113 \pm 13$ & 0400 & $99 \pm 12$ & 14.1 & $<0.01$ & $<0.01$ \\
\hline $\mathrm{DBP}(\mu \mathrm{mol} / \mathrm{l})$ & 2000 & $4.5 \pm 0.2$ & 0400 & $3.9 \pm 0.2$ & 15.4 & $<0.01$ & $<0.01$ \\
\hline Free vitamin $\mathrm{D}$ index $\left(\times 10^{-5}\right)$ & 0800 & $2.4 \pm 0.3$ & 1600 & $2.6 \pm 0.3$ & 8.3 & 0.13 & 0.4 \\
\hline $\mathrm{ClCr}(\mathrm{ml} / \mathrm{s})$ & $1200-1400$ & $1.4 \pm 0.1$ & $0800-1000$ & $1.1 \pm 0.1$ & 27.3 & 0.05 & 0.46 \\
\hline TmP/GFR & $0800-1000$ & $1.1 \pm 0.1$ & $1600-2000$ & $1.3 \pm 0.1$ & 30.0 & $<0.01$ & $<0.01$ \\
\hline \multicolumn{8}{|l|}{ Urine } \\
\hline Creatinine (mmol/h) & $1400-1600$ & $0.44 \pm 0.04$ & $0800-1000$ & $0.32 \pm 0.03$ & 37.5 & 0.04 & 0.11 \\
\hline Calcium $(\mathrm{mmol} / \mathrm{h})$ & $1200-1400$ & $0.30 \pm 0.05$ & $0400-0800$ & $0.12 \pm 0.02$ & 172.7 & $<0.01$ & $<0.01$ \\
\hline Phosphate (mmol/h) & $1400-1600$ & $1.3 \pm 0.2$ & $0800-1000$ & $0.5 \pm 0.1$ & 160.0 & $<0.01$ & $<0.01$ \\
\hline
\end{tabular}

$\dagger$ Repeated measures ANOVA (effect of time). 
The bivariate correlations between examined variables are shown in Table 4 . With $1,25(\mathrm{OH})_{2} \mathrm{D}$ as the dependent variable, multiple regression analysis revealed only DPB as an independent factor $(r=0.47$,
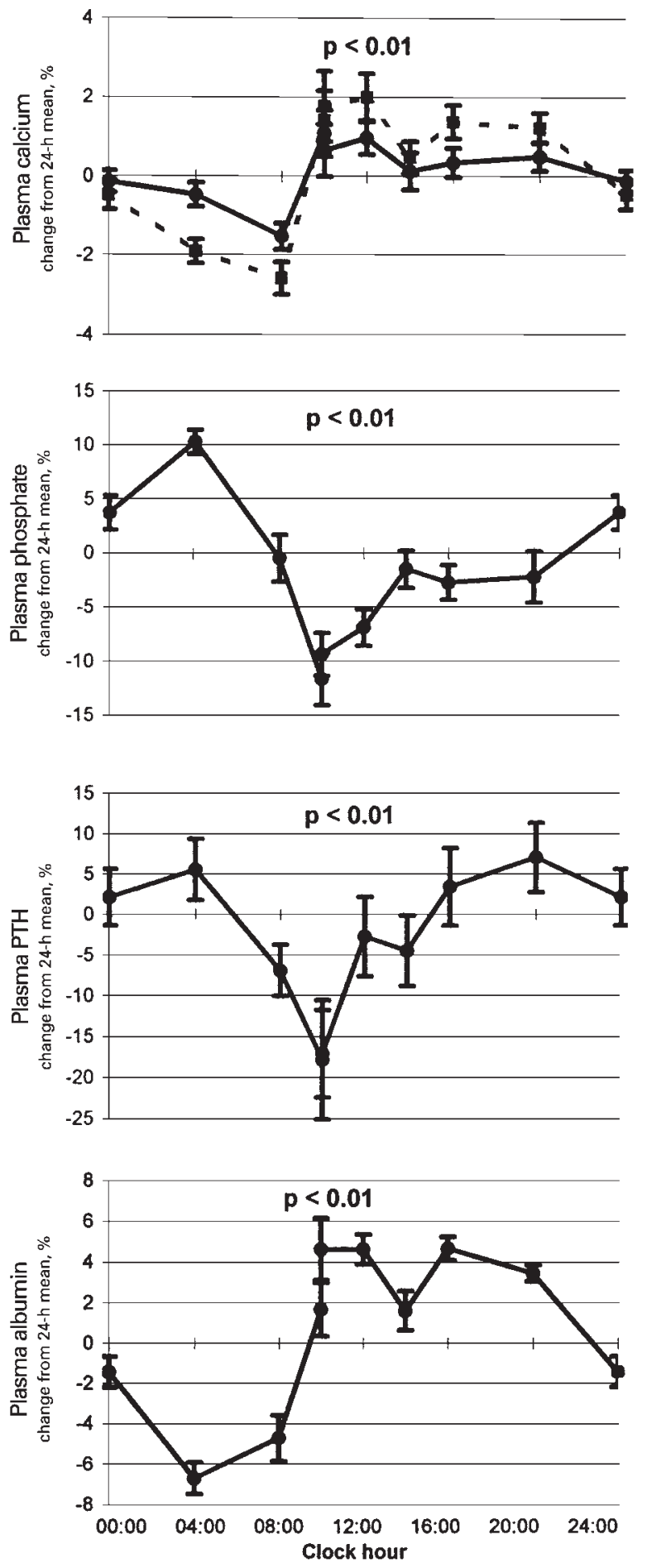

Figure 2 Diurnal variation in total plasma calcium (albumin adjusted: bold lines and unadjusted: broken line), phosphate, parathyroid (PTH) and albumin (means \pm S.E.M.).
$P=0.001)$. Although the bivariate analysis did not show any significant correlation between plasma phosphate and PTH, the multiple regression analysis revealed plasma phosphate as an independent determinant for PTH: P-PTH $=-0.46 \times \mathrm{P}-\mathrm{Ca}+0.35 \times$ $\mathrm{P}$-albumin $+0.27 \times \mathrm{P}-\mathrm{Ph}+0.0001 \quad(r=0.47, \quad \mathrm{P}<$ 0.001). Plasma PTH and albumin were the major determinants of plasma calcium and phosphate: $\mathrm{P}-\mathrm{Ca}=0.41 \times \mathrm{P}$-albumin $-0.37 \times \mathrm{P}-\mathrm{PTH}+0.0008$ $(r=0.55, \quad P<0.001), \quad$ and $\quad \mathrm{P}-\mathrm{Ph}=-0.52 \times$ P-albumin $+0.18 \times \mathrm{P}-\mathrm{PTH}+0.0007 \quad(r=0.54, \mathrm{P}<$ $0.001)$. Regarding renal excretion rates, urinary calcium varied as a function of: $\mathrm{U}-\mathrm{Ca}=0.61 \times$ $\mathrm{ClCr}-0.28 \times \mathrm{P}-\mathrm{Ph}+0.20 \times \mathrm{P}-1,25(\mathrm{OH})_{2} \mathrm{D}+0.24 \times$ $\mathrm{P}-\mathrm{Ca}+0.19 \times \mathrm{P}-\mathrm{PTH}+0.006(r=0.74, \mathrm{P}<0.001)$. Similarly, several independent factors were shown to influence renal phosphate excretion rates: $\mathrm{U}-\mathrm{Ph}=$ $0.66 \times \mathrm{ClCr}+0.35 \times \mathrm{P}-\mathrm{PTH}+0.22 \times \mathrm{P}-1,25(\mathrm{OH})_{2} \mathrm{D}+$ $0.17 \times \mathrm{P}-\mathrm{Ca}+0.15 \times \mathrm{P}-\mathrm{Ph}+0.0002(r=0.80, \mathrm{P}<$
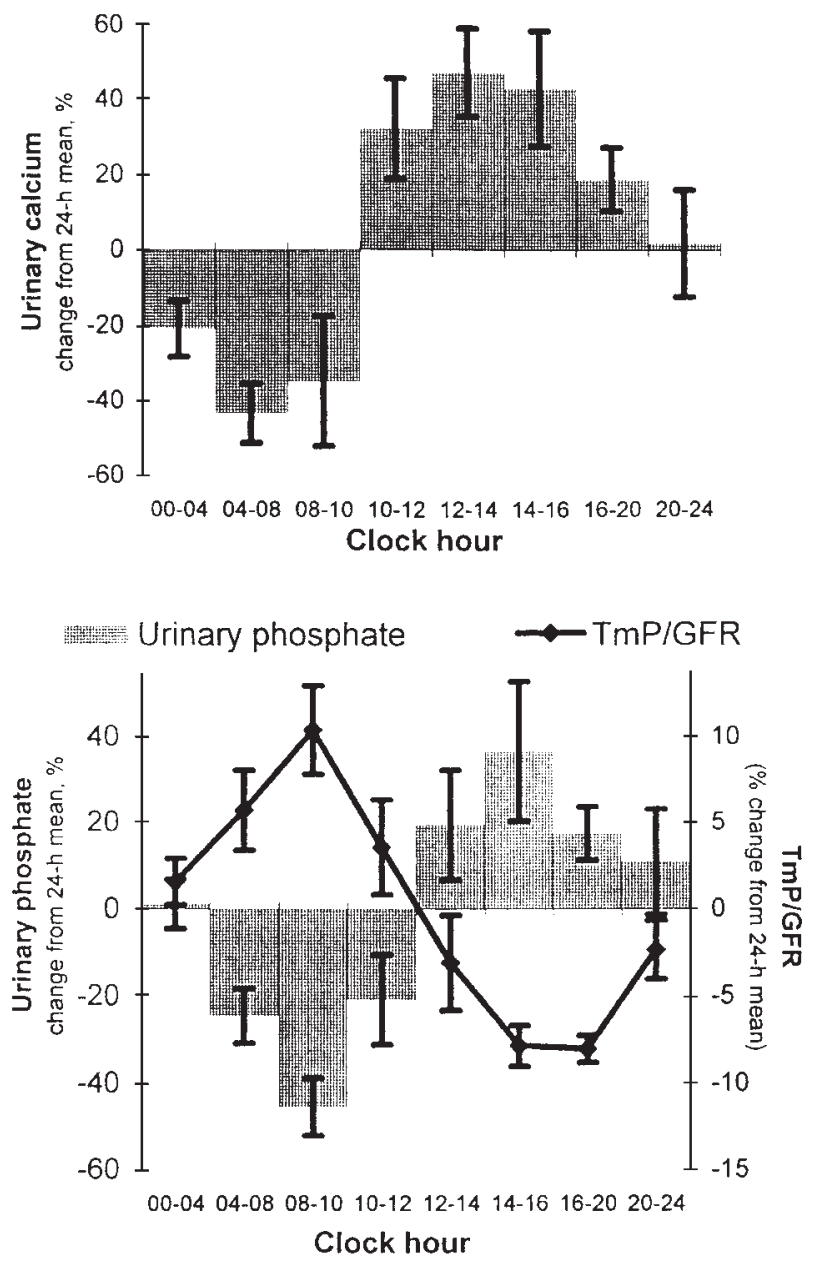

Figure 3 Diurnal variation in tubular maximum reabsorption of phosphate/glomerular filtration rate ratio (TmP/GFR) and renal excretion rates of calcium and phosphate (means \pm S.E.M.). 
Table 4 Bivariate correlation coefficients.

\begin{tabular}{|c|c|c|c|c|c|c|c|c|c|}
\hline & P-Ca (adj.) & P-Ph & P-PTH & $\mathrm{P}-1.25(\mathrm{OH})_{2} \mathrm{D}$ & P-DBP & P-albumin & U-Ca & U-Ph & TmP/GFR \\
\hline P-Ca (adj.) & - & -0.16 & $-0.36^{\star \star}$ & 0.11 & $0.26^{*}$ & $0.40^{\star *}$ & $0.21^{*}$ & 0.01 & -0.05 \\
\hline $\mathrm{P}-\mathrm{Ph}$ & -0.16 & - & 0.16 & $-0.25^{\star}$ & $-0.49^{*}$ & $-0.51^{\star *}$ & $-0.27^{\star *}$ & 0.20 & -0.09 \\
\hline P-PTH & $-0.36^{\star \star}$ & 0.16 & - & 0.09 & 0.08 & 0.03 & 0.05 & $0.31^{* *}$ & $-0.41^{* \star}$ \\
\hline $\mathrm{P}-1.25(\mathrm{OH})_{2} \mathrm{D}$ & 0.11 & $-0.25^{\star}$ & 0.09 & - & $0.47^{* *}$ & $0.35^{\star *}$ & $0.35^{\star *}$ & $0.27^{\star \star}$ & $-0.43^{\star *}$ \\
\hline P-DBP & $0.26^{\star}$ & $0.49^{* *}$ & 0.08 & $0.47^{\star \star}$ & - & $0.76^{\star \star}$ & $0.38^{\star \star}$ & 0.15 & $-0.26^{\star \star}$ \\
\hline P-albumin & $0.40^{\star *}$ & $-0.51^{* *}$ & 0.03 & $0.35^{\star *}$ & $0.76^{\star *}$ & - & $0.52^{\star \star}$ & $0.28^{* *}$ & $-0.39^{* *}$ \\
\hline U-Ph & 0.01 & 0.20 & $0.31^{\star *}$ & $0.27^{\star \star}$ & 0.15 & $0.28^{\star *}$ & $0.65^{\star \star}$ & - & $-0.75^{\star \star}$ \\
\hline TmP/GFR & -0.05 & -0.09 & $-0.41^{\star \star}$ & $-0.43^{\star \star}$ & $-0.26^{\star \star}$ & $-0.39^{\star \star}$ & $-0.47^{\star \star}$ & $-0.75^{\star \star}$ & - \\
\hline
\end{tabular}

${ }^{*}$ Correlation is significant at the 0.05 level (2-tailed). ${ }^{* *}$ Correlation is significant at the 0.01 level (2-tailed).

adj., adjusted values.

0.001). Furthermore, TmP/GFR was found to be determined by more than one independent predictor: $\mathrm{TmP} /$ $\mathrm{GFR}=-0.30 \times \mathrm{P}-1,25(\mathrm{OH})_{2} \mathrm{D}-0.38 \times \mathrm{P}-\mathrm{PTH}-$ $0.28 \times$ P-albumin $+0.0001(r=0.62, P<0.001)$.

\section{Discussion}

We have shown that plasma levels of DBP and total $1,25(\mathrm{OH})_{2} \mathrm{D}$ vary in a statistically significant diurnal rhythm. Previously, only a few investigators have studied whether total plasma levels of $1,25(\mathrm{OH})_{2} \mathrm{D}$ vary in a diurnal pattern. In six young males and seven young females (aged 20-34 years), Prince et al. (9) did not find any significant variation in plasma concentrations of $1,25(\mathrm{OH})_{2} \mathrm{D}$ as a function of time when examined between 0800 and $2200 \mathrm{~h}$. Similarly, Adams et al. (8) and Halloran et al. (7) reported that the plasma levels of $1,25(\mathrm{OH})_{2} \mathrm{D}$, in eleven young males and females (aged 19-48 years) and five young males (aged 21-40 years) respectively, were maintained within relatively narrow limits when measured for a 24-h period. The discrepancy between our present and previous studies may have several reasons. The definition of the $1,25(\mathrm{OH})_{2} \mathrm{D}$ diurnal curve in our study may reflect an improvement in assay technique. Furthermore, we cannot dismiss the possibility that the use of eleven or fewer subjects in previous studies have limited their ability to observe a time-effect. Finally, our participants were postmenopausal women, who had previously sustained a distal forearm fracture, whereas the subjects formerly studied were healthy young men and women. Changes in indices of calcium homeostasis and bone metabolism have been shown to occur with advancing age. An agerelated increase in PTH and bone turnover as well as an age-related decrease in intestinal calcium absorption and plasma level of $1,25(\mathrm{OH})_{2} \mathrm{D}$ have been shown by several investigators (12-15). Moreover, a greater amplitude in the diurnal rhythm of PTH has been observed in normal than in osteoporotic subjects (4). Therefore, the discrepancy between our findings and the results of earlier investigations may be related to differences in the physiological state of calcium homeostasis in the subjects studied.

However, we believe that our findings of a diurnal rhythm in plasma levels of total $1,25(\mathrm{OH})_{2} \mathrm{D}$ and DBP most likely reflect alterations in plasma volume, as the diurnal changes in both parameters correlated with the concomitant changes in plasma albumin levels. In normal subjects, blood volume is lower during the day than during the night, as upright posture is associated with a fluid shift from the vascular to the extravascular compartment (16). Thus, the low level of plasma $1,25(\mathrm{OH})_{2} \mathrm{D}$ at night is probably not due to a decreased endogenous synthesis of $1,25(\mathrm{OH})_{2} \mathrm{D}$, but is more likely to be the results of nocturnal haemodilution. As plasma levels of DBP also decrease due to haemodilution in the night, the free concentration of $1,25(\mathrm{OH})_{2} \mathrm{D}$ seems to remain at a steady level during the day and the night. Nevertheless, several biological functions have been associated with DBP, including binding to cell surfaces that may facilitate the release and subsequent entry of vitamin D into target cells $(17,18)$. Thus, the diurnal rhythm in plasma DBP levels may, by itself, be of biological importance.

Our data on the diurnal pattern of plasma phosphate and urinary phosphate excretion rates are consistent with previous studies (19-22). The diurnal variation in plasma phosphate is independent of physical activity and it is unaffected by prolonged bed rest, but food intake is a major determinant (20). Next to PTH, phosphate is the second most important physiological regulator of renal $1 \alpha$-hydroxylase. High phosphate levels suppress and low levels increase the enzyme activity in accordance with our finding of an inverse relation between the two plasma compounds. In humans, phosphate restriction increases plasma $1,25(\mathrm{OH})_{2} \mathrm{D}$ by approximately $180 \%$ and phosphate supplementation decreases $1,25(\mathrm{OH})_{2} \mathrm{D}$ levels by $60 \%$ (23). However, in our study, total plasma $1,25(\mathrm{OH})_{2} \mathrm{D}$ as well as the free $1,25(\mathrm{OH})_{2} \mathrm{D}$ index showed a nadir in the morning with an increase in the day time during which regular meals were served. This temporal sequence does not support the concept that the circadian variations in 
plasma $1,25(\mathrm{OH})_{2} \mathrm{D}$ observed in the present study were triggered by the meals.

We found a diurnal pattern of plasma total and albumin-adjusted calcium similar to that reported in previous studies with low levels during the night, a peak in the forenoon and high levels during the day (19, 20, 24). Our finding that plasma calcium and PTH levels correlated negatively is in agreement with most previous studies (24). Food intake is known to be a major determinant of renal calcium excretion, as a rapid rise in calcium excretion occurs after a meal (6, 22 ). We found a highly positively correlation between renal excretion rates of calcium and phosphate that most likely reflects the effect of food intake, i.e. the highest excretion rates of calcium and phosphate are observed during the day when food is consumed. Additionally, plasma PTH and renal excretion of phosphate varied, which may be due to the well-known phosphaturic action of PTH.

Our study has several potential limitations for making general conclusions. The subjects in our study were all postmenopausal women who had previously sustained a distal forearm fracture, and therefore these data do not allow us to ascertain whether the observed pattern of variation in plasma levels of $1,25(\mathrm{OH})_{2} \mathrm{D}$ is generally present in humans, or whether it only applies to certain groups of subjects. Furthermore, blood specimens were only sampled every second to fourth hours. Consequently, the times of peak and nadir are approximate, as we did not sample blood and urine specimens every hour. However, as circulating $1,25(\mathrm{OH})_{2} \mathrm{D}$ has an estimated half-life of several hours, it is unlikely that a more frequent blood sampling would have markedly improved the definition of the diurnal $1,25(\mathrm{OH})_{2} \mathrm{D}$ variation curve (25).

The food consumed by the participants was ordinary hospital food, and they were asked to consume an amount of food equal to their habitual daily fare. We did not standardise the food consumed, as we wanted to perform our study during normal daily living conditions. If standardisation of mineral intake to a fixed common level had been performed, it could, by itself, cause biological changes due to the slow adjustment of calcium homeostasis and in particular of the skeleton to external challenges (26). Moreover, we did not measure mineral content in the food served, as we judged that our sample size did not allow for subgroup analyses.

In conclusion, in a group of postmenopausal women, we have shown a significant diurnal pattern of variation in plasma concentrations of $1,25(\mathrm{OH})_{2} \mathrm{D}$ and DBP, but not in the calculated free $1,25(\mathrm{OH})_{2} \mathrm{D}$ index. Thus, the variations were most likely caused by diurnal changes in plasma volume. In clinical studies, the diurnal variations of $1,25(\mathrm{OH})_{2} \mathrm{D}$ and DBP must be considered, i.e. blood sampling must be standardised according to the time of day.

\section{Acknowledgements}

The technical assistance of Ms Donna Lund, Ms Birthe Weinell, Ms Lisbeth Flyvbjerg and Ms Lilian Alstrup is greatly appreciated.

\section{References}

1 Bell NH. Renal and nonrenal 25-hydroxyvitamin D-1alphahydroxylases and their clinical significance. Journal of Bone and Mineral Research 199813 350-353.

2 Silver J, Moallem E, Kilav R, Sela A \& Naveh-Many T. Regulation of the parathyroid hormone gene by calcium, phosphate and 1,25-dihydroxyvitamin D. Nephrology, Dialysis and Transplantation 199813 (Suppl 1) 40-44.

3 Greenspan SL, Dresner PR, Parker RA, London D \& Ferguson L. Diurnal variation of bone mineral turnover in elderly men and women. Calcified Tissue International $199760419-423$.

4 Eastell R, Calvo MS, Burritt MF, Offord KP, Russell RG \& Riggs BL. Abnormalities in circadian patterns of bone resorption and renal calcium conservation in type I osteoporosis. Journal of Clinical Endocrinology and Metabolism 1992 74 487-494.

5 Nielsen HK, Brixen K \& Mosekilde L. Diurnal rhythm and 24-hour integrated concentrations of serum osteocalcin in normals: influence of age, sex, season, and smoking habits. Calcified Tissue International $1990 \mathbf{4 7} 284-290$.

6 Calvo MS, Eastell R, Offord KP, Bergstralh EJ \& Burritt MF. Circadian variation in ionized calcium and intact parathyroid hormone: evidence for sex differences in calcium homeostasis. Journal of Clinical Endocrinology and Metabolism 199172 69-76.

7 Halloran BP, Portale AA, Castro M, Morris RCJ \& Goldsmith RS. Serum concentration of 1,25-dihydroxyvitamin $D$ in the human: diurnal variation. Journal of Clinical Endocrinology and Metabolism $1985 \mathbf{6 0} 1104-1110$.

8 Adams ND, Gray RW \& Lemann JJ. The effects of oral $\mathrm{CaCO}_{3}$ loading and dietary calcium deprivation on plasma 1,25-dihydroxyvitamin D concentrations in healthy adults. Journal of Clinical Endocrinology and Metabolism $1979 \mathbf{4 8} 1008-1016$.

9 Prince RL, Wark JD, Omond S, Opie JM, Eagle MR \& Eisman JA. A test of 1,25-dihydroxyvitamin D3 secretory capacity in normal subjects for application in metabolic bone diseases. Clinical Endocrinology $1983 \mathbf{1 8} 127-133$.

10 Lauridsen AL, Vestergaard P \& Nexo E. Mean serum concentration of vitamin D-binding protein (Gc globulin) is related to the Gc phenotype in women. Clinical Chemistry $2001 \mathbf{4 7}$ $753-756$.

11 Bijvoet OL, Morgan DB \& Fourman P. The assessment of phosphate reabsorption. Clinica Chimica Acta 196926 15-24.

12 Kinyamu HK, Gallagher JC, Petranick KM \& Ryschon KL. Effect of parathyroid hormone (hPTH[1-34]) infusion on serum 1,25dihydroxyvitamin D and parathyroid hormone in normal women. Journal of Bone and Mineral Research 199611 $1400-1405$.

13 Ledger GA, Burritt MF, Kao PC, O’Fallon WM, Riggs BL \& Khosla $S$. Role of parathyroid hormone in mediating nocturnal and agerelated increases in bone resorption. Journal of Clinial Endocrinology and Metabolism $1995 \mathbf{8 0} 3304-3310$.

14 Tsai KS, Heath H, Kumar R \& Riggs BL. Impaired vitamin D metabolism with aging in women. Possible role in pathogenesis of senile osteoporosis. Journal of Clinical Investigation 198473 $1668-1672$.

15 Gallagher JC, Riggs BL, Eisman J, Hamstra A, Arnaud SB \& DeLuca HF. Intestinal calcium absorption and serum vitamin D metabolites in normal subjects and osteoporotic patients: effect of age and dietary calcium. Journal of Clinical Investigation 1979 $64729-736$. 
16 Faweett JK \& Wynn V. Effects of posture on plasma volume and some blood constituents. Journal of Clinical Pathology 196013 304-310.

17 Berg JP. Vitamin D-binding protein prevents vitamin D deficiency and presents vitamin D for its renal activation. European Journal of Endocrinology $1999141321-322$.

18 Safadi FF, Thornton P, Magiera H, Hollis BW, Gentile M, Haddad JG et al. Osteopathy and resistance to vitamin D toxicity in mice null for vitamin D binding protein. Journal of Clinical Investigation $1999103239-251$.

19 Markowitz M, Rotkin L \& Rosen JF. Circadian rhythms of blood minerals in humans. Science $1981 \mathbf{2 1 3} 672-674$.

20 Jubiz W, Canterbury JM, Reiss E \& Tyler FH. Circadian rhythm in serum parathyroid hormone concentration in human subjects: correlation with serum calcium, phosphate, albumin, and growth hormone levels. Journal of Clinical Investigation $1972 \mathbf{5 1}$ 2040-2046.

21 Min HK, Jones JE \& Flink EB. Circadian variations in renal excretion of magnesium, calcium, phosphorus, sodium, and potassium during frequent feeding and fasting. Federation Proceedings $196625917-921$.

22 Heaton FW \& Hodgkinson A. External factors affecting diurnal variation in electrolyte excretion with particular reference to calcium and magnesium. Clinica Chimica Acta 19638 246-254.
23 Portale AA, Halloran BP, Murphy MM \& Morris RC. Oral intake of phosphorus can determine the serum concentration of 1,25dihydroxyvitamin $\mathrm{D}$ by determining its production rate in humans. Journal of Clinical Investigation 198677 7-12.

24 Markowitz ME, Arnaud S, Rosen JF, Thorpy M \& Laximinarayan S. Temporal interrelationships between the circadian rhythms of serum parathyroid hormone and calcium concentrations. Journal of Clinical Endocrinolology and Metabolism $1988 \mathbf{6 7}$ 1068-1073.

25 Mawer EB, Backhouse J, Davies M, Hill LF \& Taylor CM. Metabolic fate of administered 1,25-dihydroxycholecalciferol in controls and in patients with hypoparathyroidism. Lancet 1976 i $1203-1206$.

26 Jensen FT, Charles P, Mosekilde L \& Hansen HH. Calcium metabolism evaluated by 47 calcium-kinetics: a physiological model with correction for faecal lag time and estimation of dermal calcium loss. Clinical Physiology 19833 187-204.

Received 20 November 2001

Accepted 26 January 2002 